\title{
Screening of Bacteriocin-producing Enterococcus faecalis Strains for Antagonistic Activities against Clostridium perfringens
}

\author{
Sun-Kyung Han, Myeong-Su Shin, Ho-Eun Park, So-Young Kim¹, and Wan-Kyu Lee* \\ College of Veterinary Medicine, Chungbuk National University, Cheongju 362-763, Korea \\ ${ }^{1}$ Functional Food \& Nutrition Division, Department of Agrofood Resource, National Academy of Agricultural Science, \\ Rural Development Administration, Jeonju 560-500, Korea
}

\begin{abstract}
This study was conducted to isolate and characterize bacteriocin-producing bacteria against Clostridium perfringens $(C$. perfringens) from domestic animals to determine their usefulness as probiotics. Bacteriocin-producing bacteria were isolated from pig feces by the spot-on-lawn method. A total of 1,370 bacterial stains were isolated, and six were tentatively selected after identifying the inhibitory activity against the pathogenic indicator C. perfringens KCTC 3269 and KCTC 5100. The selected strains were identified as Enterococcus faecalis (E. faecalis) by 16s rRNA sequencing. Most of the isolated bacterial strains were resistant to $0.5 \%$ bile salts for $48 \mathrm{~h}$ and remained viable after $2 \mathrm{~h}$ at $\mathrm{pH} 3.0$. Some E. faecalis also showed strong inhibitory activity against Listeria monocytogenes KCTC 3569, KCTC 3586 and KCTC 3710. In the present study, we finally selected E. faecalis AP 216 and AP 45 strain based on probiotic selection criteria such as antimicrobial activity against $C$. perfringens and tolerance to acid and bile salts. The bacteriocins of $E$. faecalis AP 216 and AP 45 strains were highly thermostable, showing anticlostridial activities even after incubation at $121^{\circ} \mathrm{C}$ for $15 \mathrm{~min}$. These bacteriocinproducing bacteria and/or bacteriocins could be used in feed manufacturing as probiotics as an alternative to antibiotics in the livestock industry.
\end{abstract}

Keywords: antimicrobial activity, bacteriocin, probiotics, Clostridium perfringens

\section{Introduction}

Lactic acid bacteria (LAB) show antagonistic actions against spoilage and pathogenic organisms because they produce organic acids, fatty acids, hydrogen peroxide, diacetyl, and substances endowed with antibiotic activity (Ouwehand and Vesterlund, 1998). LAB also produce antimicrobial substances such as bacteriocins, which are generally defined as ribosomally synthesized peptides or proteins with bactericidal actions that often target bacterial species closely related to the producer strain (Klaenhammer, 1993). These compounds have attracted great interest because of their potential use as food preservatives, therapeutic agents against Gram positive bacteria and several viruses, and importance in modifying gut microflora (Daeschel et al., 1990; Gould, 1996; Klaenhammer, 1993; Shearer et al., 2014). Nevertheless, little

*Corresponding author: Wan-Kyu Lee, College of Veterinary Medicine, Chungbuk National University, Cheongju 362-763, Korea. Tel: +82-43-261-2960, Fax: +82-43-267-3150, E-mail: wklee@cbu.ac.kr is known about the bacteriocin-producing intestinal LAB induced animal sources (Diez-Gonzalez, 2007; Strompfová, 2006).

Clostridium perfringens ( $C$. perfringens) is widely distributed in the environment, food and intestine as the normal gut flora in humans and animals (Steele and Wright, 2001). This microorganism forms additional toxins that have been proposed to be important for the pathogenesis of intestinal disorders. This microorganism causes problems such as gas gangrene, phlegmon and food poisoning in humans, as well as fatal enterotoxaemia in various animals (Timoney et al., 1998). Although this pathogen can be controlled through hygienic methods and antimicrobial agents, the rise of multiple antibiotic drugs has created concerns regarding the possibility of antibiotic residues, development of antibiotic-resistant bacteria, imbalance of beneficial normal gut flora, and a reduction in the ability to cure bacterial infections in humans and animals (Jensen, 1998).

Therefore, in this study, we attempted to isolate and characterize bacteriocin-producing bacteria with antagonistic activities against $C$. perfringens from domestic ani- 
mals and to develop a potential candidate for probiotic use in domestic animals as an alternative to antibiotics.

\section{Material and Methods}

\section{Bacterial strains and culture condition}

Enterococcus faecalis (E. faecalis) AP 110, AP 216, AP 44, AP 45, AP 47 and AP 51 strains were isolated from the feces of pigs and maintained at $-70^{\circ} \mathrm{C}$ in $\mathrm{MRS}$ broth (Difco Laboratories, Detroit, MI, USA) containing $50 \%$ glycerol. Indicator microorganisms used in this study were obtained from the Korean Collection for Type Culture (KCTC), Korean Culture Center of Microorganisms ( $\mathrm{KC} \mathrm{CM}$ ) and our collection from domestic animals for further studies (Table 1). The organism was propagated in appropriate media such as BHI or MRS broth.

\section{Isolation of $\mathrm{LAB}$ from the feces of pigs}

Feces obtained from slaughterhouses and farms were put into transport anaerobic medium (BHI broth; brain heart infusion $37.0 \mathrm{~g}$, yeast extract $5.0 \mathrm{~g}, 0.1 \%$ resazurin

Table 1. Antimicrobial spectrum of the selected Enterococcus faecalis strains isolated from the intestine of pigs against various indicator organisms

\begin{tabular}{|c|c|c|c|c|c|c|}
\hline \multirow{3}{*}{ Indicator organisms } & \multicolumn{6}{|c|}{ Enterococcus faecalis } \\
\hline & \multicolumn{6}{|c|}{ AP } \\
\hline & $\overline{110}$ & 216 & 44 & 45 & 47 & 51 \\
\hline Bacillus cereus KCTC 1012 & - & - & - & - & - & - \\
\hline Clostridium perfringens КCТC 3269 & + & + & + & + & + & + \\
\hline Clostridium perfringens КCТC 5100 & + & - & + & + & + & - \\
\hline Enterococcus faecalis KCTC 2011 & - & - & - & + & - & - \\
\hline Enterococcus faecium KCTC 3122 & - & - & - & - & - & - \\
\hline Enterococcus durans KCTC 3121 & - & - & - & - & - & - \\
\hline Escherichia coli KCTC 1682 & - & - & - & - & - & - \\
\hline Klebsiella pneumoniae KCTC 2208 & - & - & - & - & - & - \\
\hline Lactobacillus brevis KCTC 3498 & - & - & - & + & - & - \\
\hline Lactobacillus casei KCTC 3110 & - & - & - & - & - & - \\
\hline Lactobacillus delbruekii KCTC 1047 & - & - & - & + & - & - \\
\hline Lactobacillus fermentum KCTC 3112 & - & - & - & - & - & - \\
\hline Lactobacillus plantarum KCTC 3108 & - & - & - & + & - & - \\
\hline Leuconostoc mesenteroides KCTC 3505 & - & - & - & - & - & - \\
\hline Listeria monocytogenes KCТC 3569 & + & + & + & + & + & - \\
\hline Listeria monocytogenes КСТC 3586 & + & + & + & + & + & - \\
\hline Listeria monocytogenes KCTC 3710 & + & + & + & + & + & - \\
\hline Pediococcus acidilactici KCTC 1626 & - & - & - & - & - & - \\
\hline Proteus mirabillis KCTC 2565 & - & - & - & - & - & - \\
\hline Pseudomonas aeruginosa KCTC 1750 & - & - & - & - & - & - \\
\hline Salmonella Enteritidis KCCM 12021 & - & - & - & - & - & - \\
\hline Salmonella Typhimurium KCTC 2515 & - & - & - & - & - & - \\
\hline Staphylococcus aureus KCTC 1621 & - & - & - & - & - & - \\
\hline Staphylococcus intermedius KCTC 3344 & - & - & - & - & - & - \\
\hline Streptococcus mutans KCTC 3300 & - & - & - & - & - & - \\
\hline
\end{tabular}

$1.0 \mathrm{~mL}, 0.1 \%$ hemin $1.0 \mathrm{~mL}$, and agar $0.7 \mathrm{~g}$ per $\mathrm{L}$ ) that was replaced with $\mathrm{O}_{2}$-free $\mathrm{CO}_{2}$ gas and transported immediately to a laboratory. The samples were then serially diluted ten-fold with sterile diluent $\mathrm{A}\left(\mathrm{KH}_{2} \mathrm{PO}_{4} 0.5 \mathrm{~g}, \mathrm{Na}_{2}\right.$ $\mathrm{HPO}_{4} 6.0 \mathrm{~g}$, L-cysteine $\mathrm{HCl} 0.5 \mathrm{~g}$, Tween $800.5 \mathrm{~g}$, and agar $1.0 \mathrm{~g}$ per L) plated on BHI or MRS agar and incubated at $37^{\circ} \mathrm{C}$ for $48 \mathrm{~h}$ under anaerobic conditions in an anaerobic steel wool jar filled with $\mathrm{O}_{2}$-free $\mathrm{CO}_{2}$ gas (Mitsuoka, 1980; Parker, 1955). After incubation, approximately twenty colonies per sample were randomly selected with sterilized toothpicks and inoculated into $1 \mathrm{~mL}$ BHI or MRS broth in an Eppendorf tube. The isolates were subsequently grown overnight at $37^{\circ} \mathrm{C}$, after which $3 \mu \mathrm{L}$ of culture broth were spotted on BHI agar, which were closely streaked of an overnight culture of $C$. perfringens KCTC 3269 (at a level of about $1.0 \times 10^{7} \mathrm{CFU} /$ $\mathrm{mL}$ ) using a sterile cotton swap (Teo and Tan, 2005). After incubation for $24 \mathrm{~h}$, colonies with a clear inhibition zone were further examined for the production of bacteriocin.

\section{Detection of bacteriocin-producing bacteria and spectrum of antimicrobial activity}

Cells were pelleted by centrifugation $(7000 \mathrm{~g}$ for 10 $\min$ ), after which the supernatants were adjusted to $\mathrm{pH}$ 6.5 with $1 \mathrm{~N} \mathrm{NaOH}$, filtered through $0.2 \mu \mathrm{m}$ pore size membrane filters, and used to detect antagonistic activity against indicator organisms according to the spot-on-lawn method (Mayr-Harting et al., 1972). The supernatants were serially diluted, and $10 \mu \mathrm{L}$ aliquots of samples were spotted onto the surface of soft BHI or MRS agar $(0.7 \%)$ seeded with an overnight culture of an indicator strain. In the case of Clostridium spp., an overnight culture was closely streaked onto the surface of BHI agar using a sterile cotton swab (Teo and Tan, 2005). Following incubation for $24 \mathrm{~h}$ at an appropriate temperature, the plates were checked for inhibition zones. Bacteriocin activity was expressed in terms of arbitrary units per $\mathrm{mL}(\mathrm{AU} / \mathrm{mL})$, which was defined as the highest dilution showing definite inhibition of the indicator lawn.

\section{Identification of bacterial strains}

To identify bacteriocin-producing stains, the morphological and biochemical properties of each isolate were characterized according to Bergey's manual (Holt et al., 1994). Gram staining, cell morphology, catalase activity, salt tolerance, gas production, growth temperature range, and biochemical carbohydrate fermentation patterns were assessed using an API 20E kit (Biomérieux, France). The 16S rRNA was sequenced using a Big Dye terminator 
cycle sequencing kit (Applied BioSystems, USA), and sequences were resolved on an automated RNA sequencing system (Applied BioSystems model 3730XL, USA). The 16S rRNA sequence of each strain was aligned to the $16 \mathrm{~S}$ rRNA gene sequence of $\mathrm{LAB}$ and other related taxa to compare the levels of similarity.

\section{Growth curve and bacteriocin production in BHI medium}

The growth curve and bacteriocin production were investigated in BHI medium. Finally, selected strains ( $E$. faecalis AP 216 and AP 45) were incubated in $200 \mathrm{~mL}$ BHI broth. Temperature was maintained at $37^{\circ} \mathrm{C}$ and the $\mathrm{pH}$ was not controlled. Samples were taken at $2 \mathrm{~h}$ intervals to measure cell counts and bacteriocin activity. Viable cell counts were determined by the spread plate method on BHI agar, and bacteriocin activities against $C$. perfringens KCTC 3269 were tested by the spot-on-lawn assay (Teo and Tan, 2005).

\section{Preparation of cell-free supernatants}

Cell-culture broth was centrifuged at $10,000 \mathrm{~g}$ for 10 $\min$ at $4^{\circ} \mathrm{C}$, after which the supernatant was adjusted to pH 6.5 with $5 \mathrm{~N} \mathrm{NaOH}$ or $6 \mathrm{~N} \mathrm{HCl}$ and filter-sterilized through $0.2 \mu \mathrm{m}$ pore size membrane filters.

\section{Effects of heat, $\mathrm{pH}$ and enzymes on bacteriocin acti- vity}

The effects of heat, $\mathrm{pH}$ and enzymes on the activities of partially purified bacteriocin were examined as described by Lyon and Glatz (1993). Briefly, supernatants were treated with various enzymes at a final concentration of 1 $\mathrm{mg} / \mathrm{mL}$. All enzymes (proteinase K, protease type XIV, pepsin, trypsin, $\alpha$-amylase, $\beta$-amylase, and catalase) were dissolved in buffers recommended by the supplier (Sigma Chemical Co., USA). Mixtures were incubated at $30^{\circ} \mathrm{C}$ for $1 \mathrm{~h}$ and then heated at $80^{\circ} \mathrm{C}$ for $10 \mathrm{~min}$ to inactivate the enzymes. Cell-free supernatants were heated for 30 min at $60^{\circ} \mathrm{C}$ or $90^{\circ} \mathrm{C}$, or at $121^{\circ} \mathrm{C}$ for $15 \mathrm{~min}$, after which residual bacteriocin activity against $C$. perfringens $\mathrm{KCTC}$ 3269 was determined by the spot-on-lawn assay (Teo and Tan, 2005). To investigate the effects of $\mathrm{pH}$ on antimicrobial stability, the $\mathrm{pH}$ of the supernatants was adjusted to between 2 and 10 with either $1 \mathrm{~N} \mathrm{HCl}$ or $1 \mathrm{~N} \mathrm{NaOH}$ and then incubated at $30^{\circ} \mathrm{C}$ for $1 \mathrm{~h}$.

Survival and growth at low $\mathrm{pH}$ and in the presence of various concentrations of bile salts and temperatures Acid and bile salt tolerance were tested as described by
Shin et al. (1999). To test acid and heat tolerance, overnight cultures in BHI medium of four selected strains were harvested at $3,000 \mathrm{~g}$ for $10 \mathrm{~min}$ at $4^{\circ} \mathrm{C}$ and then washed twice with $50 \mathrm{mM}$ phosphate buffer, after which they were resuspended in $20 \mathrm{~mL}$ of the same buffer and the final $\mathrm{pH}$ was adjusted to $2.0,2.3,2.5,3.0,4.0,5.0,6.0$ and 7.0. The suspensions were then incubated at $37^{\circ} \mathrm{C}$ for $2 \mathrm{~h}$, after which the viable cell counts were determined by the spread plate method on BHI agar. For the heat tolerance test, selected strains were exposed to $50^{\circ} \mathrm{C}, 60^{\circ} \mathrm{C}$, $70^{\circ} \mathrm{C}, 80^{\circ} \mathrm{C}$ or $90^{\circ} \mathrm{C}$ for $30 \mathrm{~min}$, after which the suspensions were properly diluted and the viable cell counts were determined by the spread plate method on BHI agar. Bile tolerance was determined by spreading the cells on BHI agar plates containing oxgall bile $(0,0.05,0.1,0.3$ and $0.5 \%$, respectively). Plates were incubated at $37^{\circ} \mathrm{C}$ for $48 \mathrm{~h}$, after which the viable cell counts were determined.

\section{Results}

\section{Isolation and identification of bacteriocin-produc- ing bacteria}

A total of 1,370 strains were isolated from pig feces, 354 of which showed inhibitory activity in the first screening step (data not shown). Cell-free supernatants of these isolates were neutralized with $1 \mathrm{~N} \mathrm{NaOH}$ to eliminate the effects of organic acids, and the inhibition test against indicator organisms was conducted according to the spoton-lawn method. Six strains were tentatively selected as anti-Clostridium perfringens substance-producing candidates, each of which exhibited slightly different antimicrobial activities against the indicator, $C$. perfringens $\mathrm{KC}$ TC 3269 and KCTC 5100. The strains were characterized as Gram-positive, catalase-negative, facultative anaerobic cocci-shaped bacteria (Fig. 1). Based on comparisons of their characteristics with Bergey's manual and the results of an API test (data not shown), the isolates were classified as E. faecalis AP 110, AP 216, AP 44, AP 45, AP 47 and AP 51. The six selected strains were identified as $E$. faecalis by 16s rRNA sequencing.

\section{Spectrum of antimicrobial activity}

The cell-free supernatants were tested for their antimicrobial activities against various Gram-positive and Gramnegative bacteria using the spot-on-lawn method (Table 1). All selected strains showed relatively strong inhibitory activity against the growth of $C$. perfringens and Listeria monocytogenes (L. monocytogenes) when compared to 


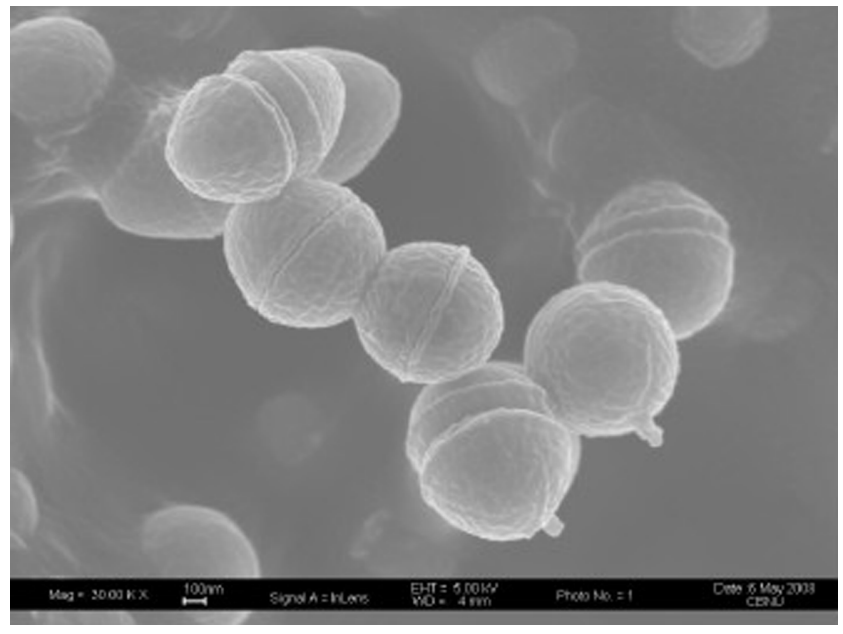

Fig. 1. Scanning electron microscopic abservation of the Enterococcus faecalis AP $216(\times 15,000)$.

other indicators. Additionally, E. faecalis AP 45 exhibited antagonistic activities against $C$. perfringens, the field isolate from domestic animals (data not shown). Particularly, E. faecalis AP 45 demonstrated a relatively broad spectrum of activity against $C$. perfringens KCTC 3269 and KCTC 5100, E. faecalis KCTC 2011, L. brevis KCTC 3498, L. delbruekii KCTC 1047, L. plantarum KCTC 3108 and L. monocytogenes KCTC 3569, KCTC 3586 and KC TC 3710 based on the spot-on-lawn method. However, they did not inhibit the growth of the Gram-negative bacteria such as Escherichia coli, Pseudomonas aeruginosa, and Salmonella Typhimurium (Table 1).

\section{Cell growth and bacteriocin production}

The bacteriocin production of E. faecalis AP 216 and AP 45 in standard cultures was detected during the exponential phase of growth, and reached maximum levels (800 and $3200 \mathrm{AU} / \mathrm{mL}$, respectively) in the stationary phase.
Table 2. Effect of enzymes, heat and $\mathrm{pH}$ on the activity of the cell-free supernatants produced by Enterococcus faecalis AP 216 and AP 45

\begin{tabular}{|c|c|c|c|}
\hline \multirow{2}{*}{\multicolumn{2}{|c|}{ Treatment }} & \multicolumn{2}{|c|}{ Relative antimicrobial activity (\%) } \\
\hline & & AP 216 & AP 45 \\
\hline \multirow{7}{*}{ Enzyme } & Proteinase K & 0 & 50 \\
\hline & Protease XIV & 0 & 25 \\
\hline & Pepsin & 25 & 0 \\
\hline & Trypsin & 0 & 0 \\
\hline & $\alpha$-Amylase & 50 & 25 \\
\hline & $\alpha$-Amylase & 50 & 25 \\
\hline & Catalase & 100 & 100 \\
\hline \multirow{3}{*}{ Heating } & $60,30 \mathrm{~min}$ & 100 & 50 \\
\hline & $90,30 \mathrm{~min}$ & 100 & 25 \\
\hline & $121,15 \mathrm{~min}$ & 100 & 25 \\
\hline \multirow{9}{*}{$\mathrm{pH}$} & $\mathrm{pH} 2.0$ & 50 & 100 \\
\hline & pH 3.0 & 100 & 100 \\
\hline & $\mathrm{pH} 4.0$ & 100 & 100 \\
\hline & pH 5.0 & 100 & 100 \\
\hline & pH 6.0 & 100 & 100 \\
\hline & $\mathrm{pH} 7.0$ & 100 & 100 \\
\hline & $\mathrm{pH} 8.0$ & 100 & 100 \\
\hline & pH 9.0 & 100 & 100 \\
\hline & pH 10.0 & 100 & 100 \\
\hline
\end{tabular}

In addition, the bacteriocin titer decreased markedly with further incubation, with no bacteriocin detected in culture supernatants at the end of the incubation period (Fig. 2).

\section{Effect of enzyme, heat treatment, and $\mathrm{pH}$ on bacte- riocin activity}

Anti-Clostridium perfringens activities of cell-free supernatants of E. faecalis AP 216 and AP 45 were completely inactivated by at least one of proteinase $\mathrm{K}$, protease XIV, pepsin, or trypsin, but they were not completely inactivated by treatment with $\alpha$-amylase, $\beta$-amylase, or catalase (Table 2). The bacteriocins of E. faecalis AP 216 strains were highly thermostable, maintaining anticlostridial acti- (a)

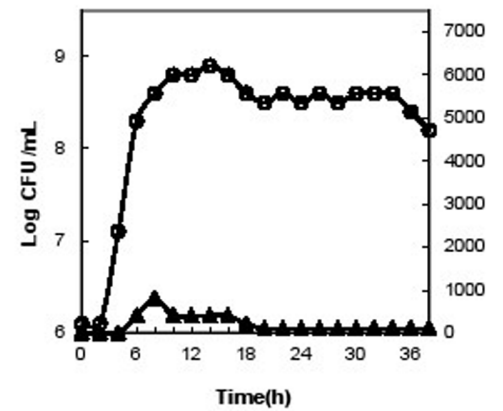

(b)

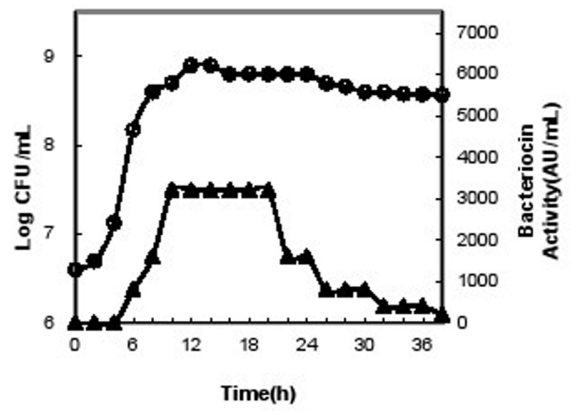

Fig. 2. Cell growth and bacteriocin production of Enterococcus faecalis AP 216 (a) and Enterococcus faecalis AP 45 (b) in BHI broth. $\bigcirc$, viable cell count; $\boldsymbol{\Lambda}$, bacteriocin activity. 
vities even after incubation at $121^{\circ} \mathrm{C}$ for $15 \mathrm{~min}$, but the inhibitory activities of $E$. faecalis AP 45 were diminished when incubated at $60^{\circ} \mathrm{C}$ or $90^{\circ} \mathrm{C}$ for $30 \mathrm{~min}$ and at $121^{\circ} \mathrm{C}$ for $15 \mathrm{~min}$. Very small or no significant decreases in the anticlostridial activities of the filtrates from selected strains were observed when they were adjusted from $\mathrm{pH} 2.0$ to 10.0 for $1 \mathrm{~h}$ compared to the untreated filtrates.

\section{Acid, bile, and heat tolerance}

The acid tolerance study showed that E. faecalis AP 216 and AP 45 strains were stable at $\mathrm{pH} 3.0$, although their viable cell number decreased after incubation at $\mathrm{pH} 2.3$ and $\mathrm{pH} 2.5$ for $2 \mathrm{~h}$, respectively (Fig. 3). In contrast to acid tolerance, E. faecalis AP 216 and AP 45 were stable following exposure to bile salt at up to $0.5 \%$ for $48 \mathrm{~h}$. To understand the influences of the thermal processing of feed containing bacteriocin-producing bacteria, preliminary examinations for heat resistance were carried out using the isolates. Two strains survived at $60^{\circ} \mathrm{C}$ for $30 \mathrm{~min}$.

\section{Discussion}

The presence of $C$. perfringens in animals has been linked to increased incidence of bovine enterotoxaemia, dia-

(a)

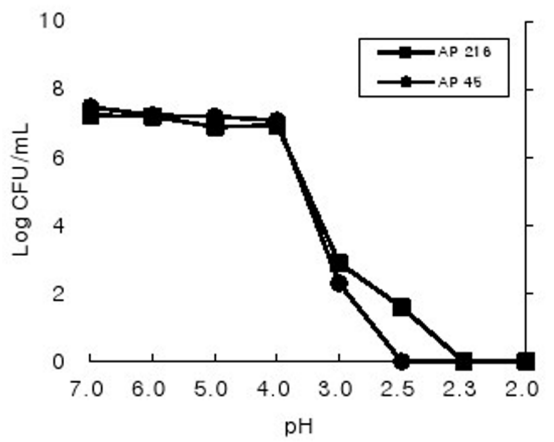

(c)

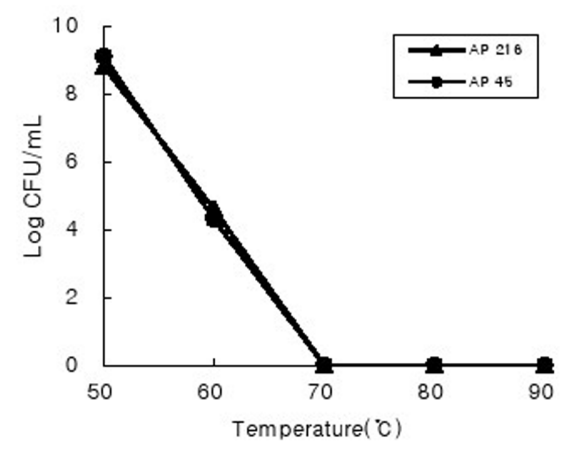

rrhea in piglets and sheep, and intestinal disorders such as necrotic enteritis in chickens (Bueschel et al., 2003; Garmory et al., 2000; Herholz et al., 1999; Klaasen et al., 1999; Manteca et al., 2002). Bacteriocin from Gram-positive microorganisms such as LAB has been subjected to intensive investigation in recent years because of the utility of biopreservatives or bioregulators and antibiotic resistance in pathogenic microorganisms such as C. perfringens (Hammerman et al., 2006; Saarela et al., 2000). In the present study, 1370 strains were isolated from the feces of domestic animals, and six E. faecalis strains were selected after determining that their anti-Clostridium perfringens activities were mediated through bacteriocin production.

Generally, most Enterococcal bacteriocin displays bacteriocidal effects (Fouquié Moreno et al., 2003; Sparo et al., 2013). Previous studies have shown that Lactobacillus rhamnosus (Alander et al., 1999), Lactobacillus plantarum (Schoster et al., 2013; West and Warner, 1988), Lactococcus lactis subsp. lactis (Harlender and Spelhaug 1989), and Pediococcus pentosaceus (Graham and McKay, 1985) are bactericidal for Clostridium spp. Additionally, we previously reported that bacteriocin-producing Bacillus strains isolated from domestic animals exhibited inhi-

(b)

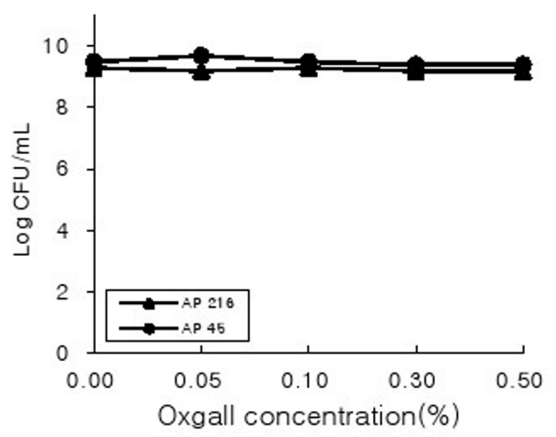


bitory activity against $C$. perfringens (Han et al. 2011). In this study, six selected E. faecalis strains were shown to exhibit various degrees of antimicrobial activity against indicator organisms. The results of the present study demonstrate anti-Clostridium perfringens bacteriocin production by $E$. faecalis for the first time. In addition, the bacteriocin of E. faecalis AP 45 was also inhibitory toward E. faecalis, L. brevis, L. delbrueki, L. plantarum and L. monocytogenes. However, it did not inhibit the growth of Gram-negative bacteria such as E. coli, P. aeruginosa, and $S$. Typhimurium.

The antimicrobial activity of bacteriocins produced by the two selected strains, E. faecalis AP 45 and AP 216, dramatically decreased at 36-48 $\mathrm{h}$ during prolonged fermentation. This pattern has been observed for other LAB bacteriocins (Aasen et al., 2000; Daba et al., 1991). Bacteriocins are often produced during the growth phase and then lost due to proteolytic degradation, protein aggregation, and adsorption by cells (Aasen et al., 2000; De Vuyst et al., 1996; Parente et al., 1994). Additionally, most authors have noted that good cell growth frequently goes hand in hand with bacteriocin production (Cabo et al., 2001; De Vuyst et al., 1996).

The effects of various enzymes on the supernatants of $E$. faecalis AP 45 and AP 216 were carefully investigated. As shown in Table 2, the antimicrobial activity of $E$. faecalis AP 216 and AP 45 were completely inactivated in response to at least one of proteinase $\mathrm{K}$, protease XIV, pepsin, or trypsin, indicating that the antimicrobial substance has a proteinaceous property that can be classified as a bacteriocin. Similar to the reported stability of bacteriocins from E. faecalis and Pediococcus acidilactici (Bhunia et al., 1987; Galvez et al., 1986), bacteriocins of the selected strains were stable in the presence of various pHs. Furthermore, their stabilities did not decrease significantly as the $\mathrm{pH}$ increased to 10 . Heat stability is very important for industrial applications such as manufacturing of animal feed. Because the two strains showed antimicrobial activities with heat stable bacteriocin, they can be used in feed manufacturing.

For probiotic application, it is important to select strains with high colony forming capacity, acid and bile resistance, inhibitory activity against pathogenic microorganisms and the ability to effectively regulate normal flora in the gastrointestinal tract (Chateau et al., 1993; Nurmi et al., 1983). Selected strains exhibited resistance to $0.5 \%$ bile salts and remained viable after $30 \mathrm{~min}$ at $\mathrm{pH}$ 3.0.

In the present study, we screened bacteriocin-producing E. faecalis strains for antagonistic activities against $C$. perfringens and finally selected E. faecalis AP 216 and AP 45 strain based on probiotic selection criteria such as antimicrobial activity against $C$. perfringens and tolerance to acid and bile salts. These bacteriocin-producing bacteria and/or bacteriocins can be used as probiotics as an alternative to antibiotics in the livestock industry.

\section{Acknowledgements}

This study was carried out with the support of "Cooperative Research Program for Agricultural Science \& Technology Development (Project No. PJ009126)", Rural Development Administration, Republic of Korea.

\section{References}

1. Aasen, I. M., Moretro, T., Katla, T., Axelsson, L., and Storro, I. (2000) Influence of complex nutrients, temperature and $\mathrm{pH}$ on bacteriocin production by Lactobacillus sakei CCUG 426 87. Appl. Microbiol. Biotechnol. 53, 159-166.

2. Alander, M., Satokari, R., Korpela, R., Saxelin, M., Vilpponen-Salmela, T., Mattila Sandholm, T., and von Wright, A. (1999) Persistence of colonization of human colonic mucosa by a probiotic strain, Lactobacillus rhamnosus GG, after oral consumption. Appl. Environ. Microbiol. 65, 351-354.

3. Bhunia, A. K., Johnson, M. C., and Ray, B. (1987) Direct detection of an antimicrobial peptide of Pediococcus acidilactici in sodium dodecyl sulfate-polyacrylamide gel electrophoresis. J. Indust. Microbiol. 2, 319-322.

4. Bueschel, D. M., Jost, B. H., Billington, S. J., Trinh, H. T., and Songer, J. G. (2003) Prevalence of $c p b 2$, encoding beta2 toxin, in Clostridium perfringens field isolates: correlation of genotype with phenotype. Vet. Microbiol. 94, 121-129.

5. Cabo, M. L., Murado, M. A., González, M., and Pastoriza, L. (2001) Effects of aeration and $\mathrm{pH}$ gradient on nisin production. A mathematical model. Enzyme Microb. Technol. 29, 264-273.

6. Chateau, N., Castellanos, I., and Deschamps, A. M. (1993) Distribution of pathogen inhibition in the Lactobacillus isolates of commercial probiotic consortium. J. Appl. Bacteriol. 74, 36-40.

7. Daba, H., Pandian, S., Gosselin, J. F., Simard, R. E., Huang, J., and Lacroix, C. (1991) Detection and activity of a bacteriocin produced by Leuconostoc mesenteroides. Appl. Environ. Microbiol. 57, 3450-3455.

8. Daeschel, M. A., McKenny, M. C., and McDonald, L. C. (1990) Bactericidal activity of Lactobacillus plantarum C11. Food Microbiol. 7, 91-98.

9. De Vuyst, L., Callewaert, R., and Crabbé, K. (1996) Primary metabolite kinetics of bacteriocin biosynthesis by Lactobacillus amylovorus and evidence for stimulation of bacteriocin under unfavourable growth conditions. Microbiol. 142, 817827.

10. Diez-Gonzalez, F. (2007) Applications of bacteriocins in live- 
stock. Curr. Issues Intestinal. Microbiol. 8, 15-24.

11. Fouquié Moreno, M. R., Callewaert, R., Devreese, B., Van Beeumen, J., and De Vuyst, L. (2003) Isolation and biochemical characterisation of enterocins produced by enterococci from different sources. J. Appl. Microbiol. 94, 214-229.

12. Galvez, A., Maqueda, M., Valdivia, E., Quesada, A., and Montoya, E. (1986) Characterization and partial purification of a broad spectrum antibiotic AS-48 produced by Streptococcus faecalis. Can. J. Microbiol. 32, 765-771.

13. Garmory, H. S., Chanter, N., French, N. P., Bueschel, D., Songer, J. G., and Titball, R. W. (2000) Occurrence of Clostridium perfringens beta2-toxin amongst animals, determined using genotyping and subtyping PCR assays. Epidemiol. Infect. 124, 61-67.

14. Gould, G. W. (1996) Industry perspectives on the use of natural antimicrobials and inhibitors for food applications. $J$. Food Prot. Suppl. 59, 82-86.

15. Graham, D. C. and McKay, L. L. (1985) Plasmid DNA in strains of Pediococcus cerevisiae and Pediococcus pentosaceus. Appl. Environ. Microbiol. 50, 532-534.

16. Hammerman, C., Bin-Nun, A., and Kaplan, M. (2006) Safety of probiotics: comparison of two popular strains. BMJ. 333, 1006-1008.

17. Han, S. K., Choi, H. J., Lee, S. M., Shin, M. S., and Lee, W. K. (2011) Screening of Bacteriocin-producing Bacillus strains isolated from domestic animal feces for antagonistic activities against Clostridium perfringens. Korean J. Food Sci. An. 31, 405-412.

18. Harlender, S. K. and Spelhaug, S. R. (1989) Inhibition of foodborne bacterial pathogens by bacteriocins from Lactococcus lactis and Pediococcus pentosaceus. J. Food Prot. 52, 856862.

19. Héchard, Y. and Sahl, H. G. (2002) Mode of action of modified and unmodified bacteriocins from Gram-positive bacteria. Biochimie. 84, 545-557.

20. Herholz, C., Miserez, R., Nicolet, J., Frey, J., Popoff, M., Gibert, M., Gerber, H., and Straub, R. (1999) Prevalence of beta2toxigenic Clostridium perfringens in horses with intestinal disorders. J. Clin. Microbiol. 37, 358-361.

21. Holt, J. G., Krieg, N. R., Sneath, P. H. A., Staley, J. T., and Williams, S. T. (1994) Bergey's Manual of Determinative Bacteriology. $9^{\text {th }}$ ed. Williams and Wilkins. Baltimore, USA.

22. Jensen, B. B. (1998) The impact of feed additives on the microbial ecology of the gut in young pigs. J Anim Feed Sci. 7, 45-64.

23. Klaasen, H. L., Molkenboer, M. J., Barkker, J., Miserez, R., Hani, H., Frey, J., Popoff, M. R., and van den Bosch, J. E. (1999) Detection of beta2 toxin gene of Clostridium perfringens in diarrhoeic piglets in the Netherlands and Switzerland. FEMS Immunol. Med. Microbiol. 24, 325-332.

24. Klaenhammer, T. R. (1993) Genetics of bacteriocins produced by lactic acid bacteria. FEMS Microbiol. Rev. 12, 39-85.

25. Lyon, W. J. and Glatz, B. A. (1993) Isolation and purification of propionicin PLG-1, a bacteriocin produced by a strain of Propionibacterium thoenii. Appl. Environ. Microbiol. 59, 8388.
26. Manteca, C., Daude, G., Jauniaux, T., Linden, A., Pirson, V., Detilleux, J., Ginter, A., Coppe, P., Kaeckenbeeck, A., and Mainil, J. G. (2002) A role for Clostridium perfringens beta2toxin in bovine enterotoxaemia. Vet. Microbiol. 86, 191-202.

27. Mayr-Harting, A., Hedges, A. J., and Berkeley, R. C. W. (1972) Methods for studying bacteriocins. Methods in Microbiology ed. Bergen T and Norris JR. pp. 315-422.

28. Mitsuoka, T. (1980) The world of anaerobic bacteria: A color atlas of anaerobic bacteria. Sobun press. Tokyo, pp. 13-65.

29. Nurmi, E. V., Schneitz, C. E., and Makela, P. H. (1983) Process for the production of a bacterial preparation. Canadian Patent no. 1151066.

30. Ouwehand, A. C. and Vesterlund, S. (1998) Antimicrobial components from lactic acid bacteria. In Lactic acid bacteria: Microbial Ecology and Functional Aspects, 2nd ed. pp. 139159. [Salminen S and von Wright A, editors]. New York: Marcel Dekker Inc.

31. Parente, E., Ricciardi, A., and Addario, G. (1994) Influence of $\mathrm{pH}$ on growth and bacteriocin production by Lactococcus lactis subsp. lactis $140 \mathrm{Nwc}$ during batch fermentation. Appl. Microbiol. Biotechnol. 41, 388-394.

32. Parker, C. A. (1955) Anaerobiosis with iron wool. Aust. J Exp. Biol. Med. Sci. 33, 33-37.

33. Saarela, M., Mogensen, G., Fondén, R., Mättö, J., and Mattila-Sandholm, T. (2000) Probiotic bacteria: safety, functional and technological properties. J. Biotechnol. 84, 197-215.

34. Schoster, A., Kokotovic, B., Permin, A., Pedersen, P. D., Dal Bello, F., and Guardabassi, L. (2013) In vitro inhibition of Clostridium difficile and Clostridium perfringens by commercial probiotic strains. Anaerobe. 20, 36-41.

35. Shearer, A. E., Hoover, D. G., and Kniel, K. E. (2014) Effect of bacterial cell-free supernatants on infectivity of norovirus surrogates. J. Food Prot. 77, 145-149.

36. Shin, M. S., Kim, H. M., Kim, K. T., Huh, C. S., Bae, H. S., and Baek, Y. J. (1999) Selection and characteristics of Lactobacillus acidophilus isolated from Korean feces. Kor. J. Food Sci. Technol. 31, 495-501.

37. Sparo, M. D., Confalonieri, A., Urbizu, L., Ceci, M., and Bruni, S. F. (2013) Bio-preservation of ground beef meat by Enterococcus faecalis CECT7121. Braz. J. Microbiol. 44, 43-49.

38. Steele, F. M. and Wright, K. H. (2001) Cooling rate effect on outgrowth of Clostridium perfringens in cooked, ready-toeat turkey breast roasts. Poultry Sci. 80, 813-816.

39. Strompfová, V., Marcináková, M., Simonová, M., Gancarcíková, S., Jonecová, Z., Sciranková, L., Koscová, J., Buleca, V., Cobanová, K., and Lauková, A. (2006) Enterococcus faecium EK13-an enterocin a-producing strain with probiotic character and its effect in piglets. Anaerobe. 12, 242-248.

40. Teo, A. Y. and Tan, H. M. (2005) Inhibition of Clostridium perfringens by a novel strain of Bacillus subtilis isolated from the gastrointestinal tracts of healthy chickens. Appl. Environ. Microbiol. 71, 4185-4190.

41. Timoney, J. F., Gillespie, J. H., Scott, F. W., and Barlough, J. E. (1998) Hagan and Bruner's microbiology and infectious diseases of domestic animals. 8th ed, Comstock Publishing 
Associates, Ithaca and London, pp. 214-240.

42. West, C. A. and Warner, P. J. (1988) Plantacin B, a bacteriocin produced by Lactobacillus plantarum NCDO 1193. FEMS
Microbiol. Lett. 49, 163-165.

(Received 2014.6.17/Revised 2014.8.7/Accepted 2014.8.18) 